\title{
Aberrant DNA glycosylase-initiated repair pathway of free radicals induced DNA damage: implications for age-related diseases and natural aging
}

\author{
B. T. Matkarimov ${ }^{1}$, M. K. Saparbaev ${ }^{2}$ \\ ${ }^{1}$ National laboratory Astana, Nazarbayev University, \\ 53, Kabanbay batyr Ave., Astana, Kazakhstan, 010000 \\ ${ }^{2}$ CNRS UMR 8126, Universit Paris-Sud 11, Institut Gustave Roussy \\ 114, rue Edouard Vaillant, Villejuif, France, 94805 \\ murat.saparbaev@gustaveroussy.fr
}

Aerobic cellular respiration generates reactive oxygen species (ROS), which can damage macromolecules including lipids, proteins and DNA. It was proposed that aging is a consequence of accumulation naturally occurring unrepaired oxidative DNA damage. In human cells, on average approximately 2000 to 8000 DNA lesions occur per hour in each cell, or about 40000 to 200000 per cell per day. DNA repair systems are able to discriminate between regular and modified bases. For example, DNA glycosylases specifically recognize and excise damaged bases among vast majority of regular bases in the base excision repair (BER) pathway. However, mismatched pairs between two regular bases occur due to spontaneous conversion of 5-methylcytosine to thymine and DNA polymerase errors during replication. To counteract these mutagenic threats to genome stability, cells evolved special DNA repair systems that target the non-damaged DNA strand in a duplex to remove mismatched regular DNA bases. Mismatch-specific adenine- and thymine-DNA glycosylases (MutY/MUTYH and TDG/MBD4, respectively) initiated base excision repair (BER) and mismatch repair (MMR) pathways can recognize and remove normal DNA bases in mismatched DNA duplexes. Paradoxically, under certain circumstances in DNA repair deficient cells bacterial MutY and human TDG can act in the aberrant manner: MutY and TDG removes Adenine and Thymine opposite misincorporated 8-oxoguanine and damaged Adenine, respectively. These unusual activities lead either to mutations or futile DNA repair, thus indicating that the DNA repair pathways which target non-damaged DNA strand can act in aberrant manner and introduce genome instability in the presence of unrepaired DNA lesions. Evidences gathered showing that in addition to the accumulation of oxidative DNA damage in cells, the aberrant DNA repair can also contribute to cancer, brain disorders and premature senescence. This review summarises the present knowledge about the aberrant DNA repair pathways for oxidised base modifications and their possible role in aging.

K e y w o r d s: oxidative DNA damage; crystal structure; base excision repair; nucleotide incision repair; AP endonuclease.

(C) 2017 B. T. Matkarimov et al.; Published by the Institute of Molecular Biology and Genetics, NAS of Ukraine on behalf of Biopolymers and Cell. This is an Open Access article distributed under the terms of the Creative Commons Attribution License (http://creativecommons.org/licenses/by/4.0/), which permits unrestricted reuse, distribution, and reproduction in any medium, provided the original work is properly cited 
Abbreviations: ROS, reactive oxygen species; AP, apurinic/apyrimidinic site; 8-oxoG, 8-oxo-7,8dihydroguanine; 8-oxoA, 8-oxo-7,8-dihydroadenine; Fapy, formamidopyrimidines; 2-oxoA, 2-hydroxyadenine; Thymine glycol, 5,6-dihydroxy-5,6-dihydrothymine; Hx, hypoxanthine; $\varepsilon \mathrm{A}, 1, N^{6}$-ethenoadenine; 5ohC, 5-hydroxycytosine; $\varepsilon \mathrm{C}, 3, N^{4}$-ethenocytosine; 5' $S$-cdA and 5' $R$-cdA, diastereoisomeric (5' $S$ )- and $\left(5^{\prime} R\right)$-8,5'-cyclo-2'-deoxyadenosines; cdG, 8,5'-cyclo-2'-deoxyguanosine; $\mathrm{DB}[a, l] \mathrm{P}-N^{2}$-dG and $\mathrm{DB}[a, l]$ $\mathrm{P}-N^{2}$-dA, dibenzo[a,l]pyrene adduct linked to $N^{2}$ atom of $\mathrm{dG}$ and dA nucleotides, respectively; AL-dA, 7-(deoxyadenosin- $N^{6}$-yl)aristolactam; AL-dG, 7-(deoxyguanosin- $N^{2}$-yl)aristolactam; BER, base excision repair; ab-BER, aberrant BER; NIR, nucleotide incision repair; MMR, mismatch repair; NER, nucleotide excision repair; GG-NER, global genomic NER; TC-NER, transcription coupled NER; APE1/ APEX1, major human AP endonuclease 1; MPG/AAG/ANPG, human alkyl-purine DNA glycosylase; OGG1, human 8-oxoG-DNA glycosylase; AlkA, E. coli alkyl-purine DNA glycosylase; Fpg, E. coli 8-oxoG-DNA glycosylase; MutY, E. coli mismatch-specific adenine-DNA glycosylase; MUTYH, human mismatch-specific adenine-DNA glycosylases; TDG, human mismatch-specific thymine-DNA glycosylase; MBD4, human methyl-binding domain protein 4; SASP, Senescence Associated Secretory Phenotype; DDR, DNA damage response, PS, progeroid syndromes or accelerated aging; sPS, segmental progeroid syndromes.

\section{Formation and repair of DNA damage}

Sources of DNA damage. Cellular DNA is constantly challenged by various endogenous and exogenous genotoxic factors that inevitably lead to DNA damage: structural and chemical modifications of primary DNA sequence. Generation of reactive oxygen species (ROS) hydroxyl radical $\left({ }^{\circ} \mathrm{OH}\right)$, superoxide $\left({ }^{\circ} \mathrm{O}_{2}^{-}\right)$and hydrogen peroxide $\left(\mathrm{H}_{2} \mathrm{O}_{2}\right)$ supported by aerobic respiration is a major source of endogenous DNA damage. About 80 different types of base and sugar lesions induced by ROS have been identified [1]. Free radicals can damage nucleobases and sugar moieties in DNA either directly or indirectly. Hydroxyl radicals preferentially react with $\mathrm{C}_{8}$ atom of purines in DNA to generate 7,8-dihydro-8-oxoguanine (8oxoG), 7,8-dihydro-8-oxoadenine (8oxoA) and formamidopyrimidines (Fapy) [2-3], with C5-C6 double bond of pyrimidines to form glycols [4-5] and pyrimidine hydrates [6]
(Figure 1). Importantly, the major endogenous oxidized bases 8oxoG, 5-hydroxyuracil (5ohU) and 5-hydroxycytosine $(5 \mathrm{ohC})$ are miscoding and, if not repaired, lead to mutation upon replication [7-9]. Oxidation of adenine residues in DNA generates among other adducts 2-hydroxyadenine (2oxoA) [10]. Damage to the free nucleotide pool is also common and generates a similar spectrum of lesions $[2,11]$.

Metabolic activation of organic peroxides leads to the formation of methyl radicals which react with DNA and produce 8-methylguanine (8meG), a highly mutagenic DNA adduct [1213]. In addition to small base modifications, ROS can also generate bulky diastereoisomeric ( $\left.5^{\prime} S\right)$ - and (5'R)-8,5'-cyclo-2'deoxyadenosine (cdA) (Figure 1) and 8,5' $-c y$ clo-2'-deoxyguanosine (cdG) adducts. 8,5'-cyclo-2'-deoxypurines $(\mathrm{cdPu})$ are generated by hydroxyl radical attack at $\mathrm{C} 5$ ' with $\mathrm{H}$-abstraction resulting in formation of the C5'-centered sugar radical, which, in the ab- 
sence of oxygen, reacts with the $\mathrm{C} 8$ of the purine. Subsequent oxidation of the resulting N7-centered radical leads to intramolecular cyclization with the formation of a covalent bond between the $\mathrm{C} 5$ ' and $\mathrm{C} 8$ positions of the purine nucleoside. When present in DNA duplex, cdA causes large changes in backbone torsion angles, which leads to weakening of base pair hydrogen bonds and strong perturbations of the helix conformation near the lesion for both diastereoisomers. These properties of cdA adducts make them strong blocks for both DNA replication and transcription. The $S$-cdA diastereoisomer is removed in the NER pathway much less efficiently than $5^{\prime} R$-cdA and is also present at a higher background level in mouse organs [14-15]. Indirectly, ROS can generate reactive aldehydes as products of membrane lipid peroxidation (LPO), which can react with DNA bases forming exocyclic etheno $(\varepsilon)$ adducts $1, N^{6}$-ethenoadenine ( $\left.\varepsilon \mathrm{A}\right)$ and 3,N4-ethenocytosine $(\varepsilon \mathrm{C})$ [16]. Etheno adducts are ubiquitous and have been found in DNA isolated from tissues of untreated rodents and humans [17]. Importantly, $\varepsilon A$ and $\varepsilon C$ levels are significantly increased by cancer risk factors related to oxidative stress/LPO, such as dietary $\omega-6$ fatty acids intake, chronic infections and inflammatory conditions [18]. The $\varepsilon \mathrm{A}$ and $\varepsilon \mathrm{C}$ residues in DNA are highly mutagenic, especially in mammalian cells. Therefore the repair processes eliminating $\varepsilon$-adducts from DNA should play a crucial role in maintaining the stability of the genetic information.
Miscoding<smiles>[R]n1cc(O)c(N)nc1=O</smiles>

5-hydroxycytidine $C \cdot G \rightarrow T \cdot A$<smiles>[R]Nc1nc(N)[nH]c(=O)c1NC=O</smiles>

2,6-diamino-4-oxo-5formamidopyrimidine $\mathrm{G} \rightarrow \mathrm{T}, \mathrm{C}$<smiles>[R]n1c(=O)[nH]c2c(=O)[nH]c(N)nc21</smiles>

8-oxo-7,8-dihydroguanosine $\mathrm{G} \cdot \mathrm{C} \rightarrow \mathrm{T} \cdot \mathrm{A}$<smiles>[R]n1c(=O)[nH]c2c(N)ncnc21</smiles>

8-oxo-7,8-dihydroadenosine $A \rightarrow G, C$<smiles>[R]n1cnc2c(N)nc(O)nc21</smiles>

2-hydroxyadenosine

$1 N^{6}$-ethenoadenosine<smiles>[R]n1cnc2c1ncn1ccnc21</smiles><smiles>[R]N1C(=O)NC(=O)[C@](C)(O)[C@H]1O</smiles>

Thymidine glycol (5,6-dihydroxy-5,6-dihydrothymidine)

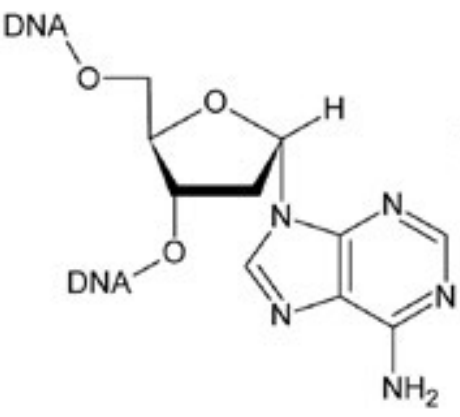

a-2'-deoxyadenosine

$\left(5^{\prime} R\right)-8,5^{\prime}$-cyclo-2'-deoxyadenosine

Fig. 1. Chemical structures of the major oxidative DNA lesions. 
In addition to endogenous oxidative stress, cells are also exposed to environmental carcinogens which induce bulky DNA adducts. Normally, they are quickly removed but some are refractory to repair. For example, exposure to aristolochic acid, a plant compound used in Chinese herbal medicine, induces aristolactam (AL)-DNA adducts including AL-dA and AL$\mathrm{dG}$ residues [19], and reactive metabolic products of the dibenzo $[a, l]$ pyrene $(\mathrm{DB}[a, l] \mathrm{P})$, a polycyclic aromatic hydrocarbon $(\mathrm{PAH})$, can generate $\mathrm{DB}[a, l] \mathrm{P}-N^{2}-\mathrm{dG}$ and $\mathrm{DB}[a, l] \mathrm{P}-N^{2}-\mathrm{dA}$ adducts [20]. Of these, the adenine derived lesions AL-dA and $\mathrm{DB}[a, l] \mathrm{P}-N^{2}-\mathrm{dA}$ are refractory to the repair machinery, likely due to the stability of DNA duplexes containing these lesions. These persistent DNA lesions can accumulate in cells and finally lead to mutations, making them highly carcinogenic.

$D N A$ repair systems. DNA repair is essential for cell survival and maintenance of tissue homeostasis. Cellular organisms must constantly contend with endogenous DNA damage and have evolved multiple DNA repair systems to deal with these insults. In general, DNA repair systems can discriminate between regular and modified bases. Indeed, oxidatively damaged DNA bases are specifically recognized among vast majority of regular bases by DNA glycosylases and apurinic/apyrimidinic (AP) endonucleases in the base excision repair (BER) and nucleotide incision repair (NIR) pathways, respectively [21-22] (Figure 2). In the classic BER pathway, a DNA glycosylase hydrolyses the $N$-glycosydic bond between the damaged base and sugar, leaving either an apurinic/apyrimidinic (AP) site or a singlestranded DNA break. In general, DNA glycosylases are highly specific enzymes excising distinct types of modified bases. DNA glycosylases are classified as mono- and bifunctional based on their mechanism of action. Monofunctional DNA glycosylases cleave the $N$-glycosydic bond, releasing the modified base and generating an AP site [23] (Figure 2A). Bifunctional glycosylases not only cleave the $N$-glycosydic bond, but also have an AP lyase activity that eliminates the 3 ' phosphate ( $\beta$-elimination) or $3^{\prime}$ and $5^{\prime}$ phosphates $(\beta, \delta$-elimination) of the resulting AP site in a concerted manner. $\beta$-Elimination produces a nick flanked by a 3'-terminal $\alpha, \beta$-unsaturated aldehyde and a 5 '-terminal phosphate, whereas $\beta, \delta$-elimination yields a single-nucleoside gap flanked by two phosphates [23-24] (Figure 2B). The 3'-terminal phosphoaldehyde or phosphate is then removed by an AP endonuclease, allowing a DNA polymerase to fill the gap and Flap structure-specific endonuclease 1 (FEN1) to remove 5' overhanging "flaps" generated during repair synthesis before DNA ligase seals the resulting DNA nick [25].

The flow of the DNA glycosylase-initiated BER pathway, which requires the sequential action of two enzymes for proper incision of DNA, raises concerns about the safety of the whole process because genotoxic abasic intermediates are generated. Findings that AP endonucleases nick DNA 5' to various oxidatively damaged nucleotides, generating 3'-hydroxyl and 5'-phosphate termini (Figure 2C), together with genetic data on the cell resistance to oxidative stress, are suggestive of the existence of an alternative to the classic BER, termed the NIR pathway, which bypasses the abasic intermediates [26]. AP endonucleases are thus multifunctional repair enzymes involved in both BER and NIR pathways. AP site nicking (or AP endonu- 
clease) and 3'-repair diesterase activities can be considered as the BER functions, and nucleotide incision activity as the NIR function of the AP endonucleases [27]. Genetic dissection of the BER and NIR functions of bacterial AP endonuclease Nfo revealed that the drug sensitivity of $E$. coli correlates with the specific lack of NIR activity, thus strengthening the physiological relevance of the NIR pathway in handling oxidative DNA damage that, when left unrepaired, leads to cell death [28]. In addition, it has been demonstrated that AP sites and certain oxidized DNA bases can be removed in the AP endonuclease-independent BER pathway which is initi-
The Base Excision Repair

Pathway (BER)
The Nucleotide Incision Repair Pathway (NIR)

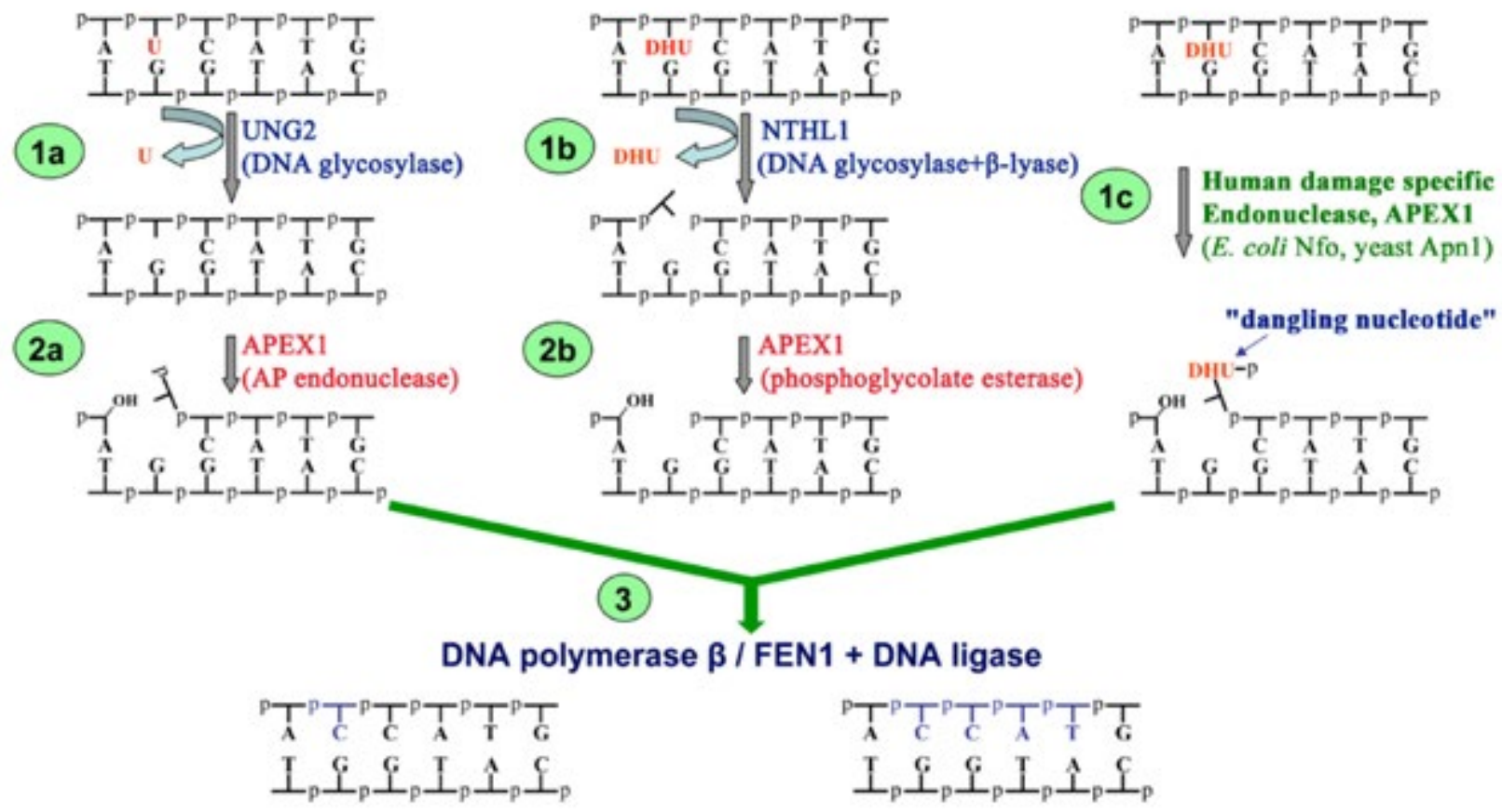

Fig. 2. BER and NIR: two alternative DNA repair pathways for DNA damage. A monofunctional DNA glycosylase, such as uracil-DNA glycosylase (UNG) excises the lesion (in this example, uracil, U) from DNA as a free base resulting in the formation of an AP site (1a); and the major AP endonuclease 1 (APEX1) hydrolyzes duplex DNA 5' to the nascent AP site yielding a single-strand break with a 3'-hydroxyl adjacent to a 2'-deoxyribose-5'-phosphate (dRp) (2a). Alternatively, a bifunctional DNA glycosylase/AP lyase, such as endonuclease III (NTHL1) excises the lesion (in this case, 5,6-dihydrouracil, DHU, or another redox-damaged pyrimidine) from DNA resulting in the formation of a single-strand break and/or one-nucleotide gap containing a 3'- $\alpha, \beta$-unsaturated aldehyde and a 5'-phosphate (1b); and the 3' repair diesterase activity of APEX1 removes the 3'-blocking group to generate a 3'-OH terminus (2b). In NIR, the branch dealing with many oxidative lesions, the endonuclease activity of APEX1 (also established for $E$. coli Nfo and yeast Apn1) directly cleaves DNA 5' to the lesion generating a single-strand nick containing a 3'-OH and a 5'-phosphate with a dangling nucleotide (1c). In both BER and NIR, (3) DNA polymerase initiates the repair synthesis coupled to removal of a 5'-dRp residue in BER or 5'-dangling nucleotide in NIR, and DNA ligase seals the remaining nick. 
ated by the tyrosyl-DNA phosphodiesterase 1 (Tdp1) and endonuclease VIII-like DNA glycosylases (NEIL). Tdp1 catalyzes the hydrolysis of the phosphodiester linkage between the DNA 3 ' phosphate and a tyrosine residue as well as a variety of other DNA 3' damaged termini. It has been shown that Tdp1 can catalyze the cleavage of AP site in DNA by hydrolysis of the phosphodiester bond between the substituent and 5' adjacent phosphate. The final product of Tdp1catalyzed AP site cleavage is a single nucleotide gap with 5' and 3'-phosphate termini [29-31]. Tdp1 is also able to effectively cleave non-nucleotide insertions in DNA, decanediol and diethyleneglycol moieties by the same mechanism [31]. Also, the BER pathway initiated by NEIL1 and NEIL2 DNA glycosylases performing $\beta, \delta$ elimination cleavage of the AP sites does not require AP endonuclease but polynucleotide kinase (PNK) which removes the 3'-phosphate in single-strand DNA break [32-33]. The complex of Tdp1, NEIL1 or NEIL2 with DNA polymerase $\beta$, and DNA ligase III $\alpha$ together with PNK suggests coordination of APE1-independent BER pathway in mammalian cells $[31,33]$.

In addition to BER and NIR, dedicated repair pathways remove bulky DNA adducts, DNADNA and DNA-protein crosslinks. Most DNA lesions produced spontaneously or induced by alkylating agents or oxygen radicals are nonbulky and are substrates for DNA glycosylases or AP endonucleases. Only a few oxidative DNA lesions, such as $\mathrm{cdPu}[14,34]$ and pyrimidopurinone [35], are substrates for nucleotide excision repair (NER) pathway due to their bulky character. In the NER pathway, a multiprotein complex recognizes and excises bulky DNA adducts in the form of short oligonucleotides that contain the lesion [36]. Interestingly, the NER pathway similar to BER is also sensitive to the damaged bases pairing, and it preferes mismatched cdPu pairs as compared to matched ones [37]. NER is a major repair system that removes DNA damage induced by UV, anticancer agents such as cisplatin, and many environmental carcinogens. In eukaryotic cells, NER involves dual incisions that bracket the lesion site and release 24-32 nucleotide-long oligomer containing the damaged residues. Two sub-pathways are identified, (i) transcription-coupled repair (TC-NER) in transcriptionally active genes and (ii) global genomic repair (GG-NER) operating on the entire genome [38]. The RNA polymerase II stalled at DNA lesions is sensed by Cockayne syndrome proteins (CSA and CSB) in TC-NER and by xeroderma pigmentosum (XPC) in GG-NER [39]. In both pathways, the lesions are excised by structure-specific endonucleases (e.g. XPG, ERCC1-XPF) and resulting DNA gap is then filled by DNA polymerases $\delta$ or $\varepsilon$ and sealed by DNA ligase I. NER also contributes to repair intra and interstrand DNA crosslinks (ICL) and oxidatively damaged DNA.

Base mispairs and short deletion-insertion loops are generated during DNA replication and homologous recombination. Mismatch repair (MMR) is an evolutionarily conserved system that recognizes and repairs mismatches in a strand-specific manner. MMR machinery is coupled to DNA replication and can distinguish the newly synthesized strand from the parental strand. In eukaryotes, the presence of nicks in the newly synthesized DNA strand provides a signal that directs the mismatch system to the appropriate strand. In human cells two major heterodimers: Msh2/Msh6 (MutS $\alpha$ ) and Msh2/Msh3 (MutS $\beta$ ) recognize DNA mismatches and trigger their removal by 
recruiting MutL $\alpha$ (MLH1/PMS2) and MutL $\beta$ (MLH1/PMS1) complexes [40]. In contrast, the so-called noncanonical MMR (ncMMR) is an $\mathrm{S}$ phase-independent process where the MMR pathway is activated by various DNA base lesions (e. g., uracil and $O^{6}$-methylguanine) rather than by mispairs containing non-damaged bases [41-42]. It was suggested that ncMMR lacks strand directionality and is required for AID-dependent somatic hypermutation of the immunoglobulin genes during antibody maturation in B cells [41].

\section{Aberrant base excision repair}

Under certain circumstances, DNA repair can go awry and aberrantly remove a non-substrate base (often undamaged). In the ensuing round of repair, some of these aberrant events lead to mutagenic repair; alternatively, the same nucleotide may be incorporated initiating multiple rounds of futile repair. Thus, aberrant base excision repair (ab-BER) can either be mutagenic or futile. One of the first evidence for the presence of futile ab-BER activity was described in 1998 when Seeberg and colleagues showed that the E. coli AlkA, S. cerevisiae MAG and human MPG/AAG/ANPG alkylpurine DNA glycosylases can excise regular purine bases from undamaged duplex DNA at measurable rates [43]. Furthermore, overexpression of AlkA and MAG in E. coli and yeast, respectively, results in increased spontaneous mutation rates [43-44]. Intriguingly, an increased level of ANPG is correlated with lung cancer risk in humans suggesting that this futile repair may contribute to carcinogenesis [45]. The aberrant futile repair activity was also demonstrated for the bacterial and human NER machinery, which can target undamaged DNA and remove oligonucleotide fragments with regular nucleotides leading to futile excision/resynthesis cycles [46]. In addition, human NER initiates futile DNA repair on DNA duplex containing interstrand cross-links by excising 22-28-mer single-stranded DNA fragment adjacent to the damaged site, without removal of the crosslinked DNA bases [47]. Since these futile excision activities of DNA repair enzymes act primarily on non-damaged DNA, their impact on the increase in spontaneous mutation frequency may be limited by the error rates of repair DNA polymerases [48].

Although, in general the DNA repair systems are highly specific for DNA modifications, challenges to the faithful discrimination between damaged and undamaged DNA strands do exist. Mispairs between two regular bases occur due to spontaneous conversion of 5-methylcytosine to thymine (a process limited to higher eukaryotes) and also due to replication errors that have escaped proofreading. Both the classic MMR pathway and BER initiated by mismatch-specific adenine- and thymine-DNA glycosylases (MutY/MUTYH and TDG or MBD4, respectively) can recognize and remove regular DNA bases in mismatched DNA duplex. However, MMR has a way to direct excision to the newly synthesized strand, whereas the DNA glycosylases excise A or T irrespectively of the strand history. Cells lacking MMR, MutY/MUTYH or MBD4 exhibit increased spontaneous mutation rates, indicating that under normal physiological conditions MMR and BER help to maintain genome stability by correcting mismatches [49-51]. However, as discussed below, these repair mechanisms can sometimes generate mutations 
by initiating aberrant repair via removal of regular bases from damaged DNA duplex.

E. coli mutY (micA) gene encodes a DNA glycosylase that excises regular A opposite $\mathrm{G}$, $\mathrm{C}$, and 8-oxoG [52-53]. In vivo, MutY protein has an antimutator effect preventing spontaneous $\mathrm{G} \bullet \mathrm{C} \rightarrow \mathrm{T} \bullet \mathrm{A}$ transversions [54]. It acts in concert with Fpg/MutM (a DNA glycosylase that removes 8 -oxoG from 8 -oxoG $\bullet C$ pairs) and MutT (an 8-oxodGTP pyrophosphohydrolase that cleanses the oxidized dNTPs pool to prevent incorporation of 8-oxodGTP during DNA synthesis) proteins in the so-called "GO system" to counteract mutagenic effect of 8-oxoG (for review see [7]). E. coli mut $Y$ mutants show 10-100 fold increased spontaneous $\mathrm{G} \cdot \mathrm{C} \rightarrow \mathrm{T} \bullet A$ transversions rate [54]. Since the bacterial MutY and human MUTYH do not discriminate between template and newly synthesized DNA strands, if 8-oxoG is misincorporated during replication opposite $\mathrm{A}$ in the template DNA strand, MutY/MUTYH would remove a correct adenine and immediately fix the mutation if $\mathrm{C}$ is incorporated during the repair synthesis. Indeed, the high frequency of spontaneous $\mathrm{A} \cdot \mathrm{T} \rightarrow \mathrm{C} \cdot \mathrm{G}$ transversions in an E. coli $m u t T$ strain are significantly reduced in strains carrying additional mut $Y$ and $m u t M$ mut $Y$ mutations, suggesting that 8-oxodGMP is preferentially incorporated opposite $\mathrm{A}$ in the template strand [55]. Furthermore, E. coli mut $Y$ and mutM mut $Y$ mutant strains show a decrease in spontaneous $\mathrm{A} \cdot \mathrm{T} \rightarrow \mathrm{C} \cdot \mathrm{G}$ transversions in the mut $T(+)$ background, suggesting that, even in the presence of a functional MutT protein, $\mathrm{A} \rightarrow \mathrm{C}$ transversions may still result from 8-oxodGMP misincorporation opposite A with the following removal of A from the template strand by MutY [55].
Biallelic mutations in the MUTYH gene, a human homologue of MutY, are associated with a hereditary colorectal cancer syndrome termed MUTYH-associated polyposis (MAP) [56]. MUTYH interacts with PCNA and RPA during DNA replication and this interaction with PCNA could direct MUTYH to the daughter strand containing mispaired A opposite 8-oxoG [57-58]. It has been proposed that the PCNA mediated directionality of MUTYH could prevent erroneous action of the DNA glycosylase on adenine in template strand when paired with incoming 8-oxodGTP. This might also help to avoid the futile MUTYH-initiated short-patch BER pathway on 8oxo-G•A duplex observed in the reconstituted in vitro system [59]. In addition, following induction of DNA damage in the cells, MUTYH can switch to interact with the heterotrimeric ring-like molecule Rad9/Rad1/ Hus1, referred as the 9-1-1 complex [60]. This interaction enhances the DNA glycosylase activity and targets MUTYH to DNA damage sites [60-61]. In support to these observations, several germline mutations in the MUTYH gene associated with a high risk of colorectal cancer have been identified that reduce ability of the MUTYH protein to interact with 9-1-1 complex without affecting its base excision repair activity [62-63]. Furthermore, it was shown that human MUTYH interacts with heterodimer MutSa via the hMSH6 subunit [64]. This interaction may facilitate MUTYHmediated excision of adenines opposite 8-oxoG and generation of single-strand breaks in the nascent strand which in turn can be used by MMR machinery as strand discrimination signals [65]. Thus the MUTYH-catalyzed repair activity is tightly controlled by the specific 
protein-protein interactions in order to reduce aberrant repair of the template strand during DNA replication.

Recently, it has been demonstrated that TDG and MBD4 initiate aberrant repair by excising $\mathrm{T}$ paired with a damaged adenine residue in duplex DNA [66] (Figure 3). TDG targets the non-damaged DNA strand and efficiently excises $\mathrm{T}$ opposite hypoxanthine (Hx), 1, $N^{6}$-ethenoadenine (EA), 8-oxoA and AP site in the $\mathrm{TpG} / \mathrm{CpX}$ sequence context, where $\mathrm{X}$ is a modified residue. MBD4 removes only $\mathrm{T}$ from pairs with $\varepsilon A$, but not with $\mathrm{Hx}$ or other damaged adenine residues. In vitro reconstitution showed that TDG-catalyzed aberrant excision of a regular thymine opposite $\mathrm{Hx}$ residue initiates repair synthesis that uses the damaged DNA template which in turn leads to a $\mathrm{T} \rightarrow \mathrm{C}$ mutation in the absence of DNA replication [66]. In mammalian cells TDG is tightly associated with euchromatin and binds the

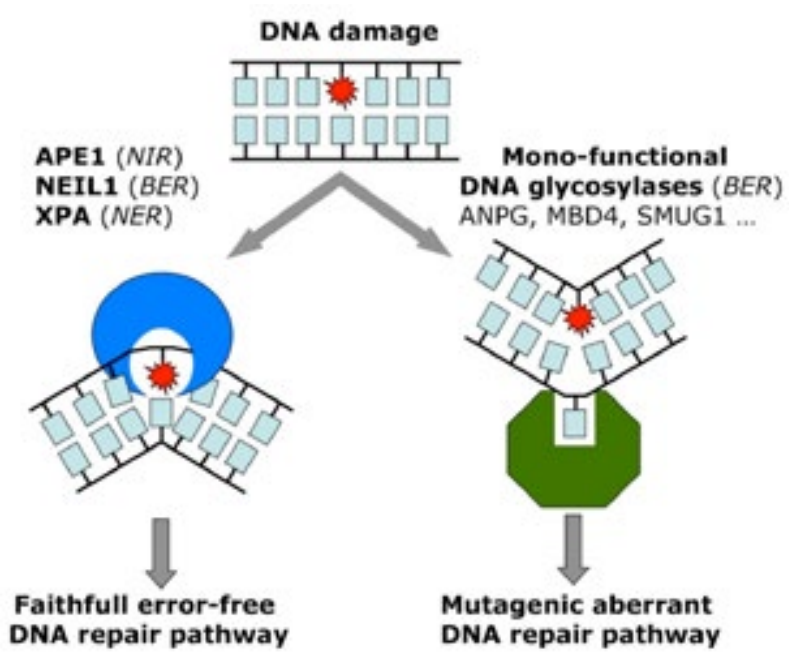

Fig. 3. Schematic representation of the faithful and aberrant DNA repair pathways. Aberrant base excision repair of DNA base damage can induce mutations in DNA replication independent manner.
CpG-rich promoters of transcribed genes to scan $\mathrm{CpG}$ sites for mismatches and to protect CpG from de novo DNA methylation [67-68]. Bioinformatic analysis of the human singlenucleotide polymorphisms (SNPs) database revealed that the spontaneous mutation spectra at $\mathrm{CpG}$ islands showed a strong mutational bias towards $\mathrm{TpG}, \mathrm{CpA} \rightarrow \mathrm{CpG}$ mutations, as compared to genome-wide mutation spectra. These prevalent $\mathrm{T} \rightarrow \mathrm{C}$ mutations in the $\mathrm{CpG}$ islands suggest that the TDG-catalyzed aberrant BER may be involved in the stabilization and extension of $\mathrm{CG}$ content in $\mathrm{CpG}$ rich promoters in vivo [66]. Thus, under certain conditions TDG can catalyze sequence context-dependent aberrant removal of thymine which may result in $\mathrm{TpG}, \mathrm{CpA} \rightarrow \mathrm{CpG}$ mutations. Taken together, these observations suggest that in the absence of efficient repair of endogenous oxidatively damaged DNA such as Hx, \&A and 8-oxoA, the post-mitotic cells could accumulate mutations because of the TDG/MBD4catalyzed aberrant excision of a regular DNA bases opposite a damaged DNA strand.

The recognition of regular $\mathrm{T}$ opposite damaged adenine by the mismatch-specific thymine-DNA glycosylase suggests that alkylpurine DNA glycosylases AlkA/ANPG and adenine-DNA glycosylases MutY/MUTYH could possibly remove regular A opposite to bases other than thymine and 8-oxoG, respectively. Indeed, it was demonstrated that AlkA/ANPG can excise $\mathrm{A}$ from $\mathrm{A} \cdot \mathrm{C}$ mismatches [69-70], while MutY/MUTYH can excise A opposite $\mathrm{G}$ [52-53]. If adenine is a correct template base in $\mathrm{A} \cdot \mathrm{C}$ and $\mathrm{A} \cdot \mathrm{G}$ mispairs, than its removal by the mismatch-specific DNA glycosylases would result in mutation fixation in absence of DNA replication. It should be noted that the 
rate of adenine removal in $\mathrm{A} \cdot \mathrm{G}$ mispair by $E$. coli MutY and mammalian MUTYH under physiological conditions is much lower as compared to that in $\mathrm{A} \bullet 8-\mathrm{oxoG}$ mispair [71-72]. Nevertheless under low ionic strength buffer conditions murine MUTYH exhibits similar activities against $\mathrm{A} \cdot \mathrm{G}$ and $\mathrm{A} \bullet 8$-oxoG duplexes $[71,73]$.

\section{Accumulation of endogenous DNA damage in non-dividing cells: the reasons and possible consequences in light of aberrant repair}

\subsection{Non-dividing cells are prone to ab- errant $D N A$ repair}

Attenuation of specific DNA repair pathways and accumulation of unrepaired DNA lesions are likely to shift the processing of DNA lesions towards pathways competing with normal repair. This makes non-dividing cells particularly prone to aberrant DNA repair. Nondividing cells are known to downregulate some of their repair pathways. It has been suggested that Global Genomic DNA Repair (GG-NER) is generally attenuated in non-dividing cells whereas transcription-coupled DNA repair (TC-NER) remains active even in non-cycling cells [74-75]. Accordingly, it was found that the cellular DNA repair machinery does not efficiently process lesions in a non-transcribed transgene until cells are induced to proliferate [74]. In fact, it seems that proliferating and non-dividing cells activate differential DNA repair pathways to preserve integrity of their genome [75-77]. Of note, DNA repair pathways involved in aberrant DNA repair such as non-canonical MMR [41] or BER [66] are generally active in non-dividing cells.
Many experimental observations support the view that DNA lesions accumulate in non-dividing cells, including reversibly growth-arrested quiescent hematopoietic or cancer stem cells [77, 78-80], and cells having undergone irreversible replicative cellular senescence [81-86] or terminal differentiation [87-89]. In quiescent hematopoietic stem cells, accumulation of DNA lesions is associated with attenuation of DNA repair and response pathways, which is reversed upon re-entry into cell cycling [77-79]. However, other mechanisms could contribute to DNA lesions accumulation in non-dividing cells. For instance, tightly packed chromatin may limit access to the DNA repair machinery $[90,91]$ which could amplify the effects of decreased GGR in non-dividing cells, whereas chromatin unpacking during DNA replication provides full access to DNA lesions during the $\mathrm{S}$ phase of cell cycle. Additionally, non-proliferating cells cannot perform serial two-fold dilution of DNA lesions through repetitive cycles of DNA replication that allow error-free copy of the damaged DNA strand by using the specific translesion synthesis DNA polymerases for certain types of DNA lesions [92]. Finally, some irreversibly growtharrested cells such as senescent cells or terminally differentiated cells like neurons with intense aerobic metabolism are thought to sustain permanent oxidative stress resulting in the generation of oxidative lesions in DNA at a high rate [88, 93-98].

\subsection{Potential detrimental effects of $a b-$ errant DNA repair in non-dividing cells}

\subsubsection{Accumulation of mutations. Completion} of an ab-BER cycle leads to mutations that could be deleterious for the cell if occurring 
in transcribed genes. Pathological effects in terminally differentiated cells could be observed only if a substantial fraction of the cells within an organ are affected, which may require long-lived non-dividing cells or hot spots of DNA damage prone to aberrant DNA repair with detrimental consequences. Accordingly, aberrant DNA repair leading to DNA trinucleotide repeat expansion in the HTT gene was shown to be the cause of the neurodegenerative Huntington's disease that usually clinically manifests between 35 and 44 years of age [99]. However, in the absence of the hot spots, it is presently unclear whether random genetic mutations could accumulate in a sufficiently large fraction of aging neurons to account for pathological effects.

Detrimental effects of mutations in nondividing cells may be also relevant for cancers as they are generally clonal diseases originating from a single mutated cell. This is clearly supported by a recent work showing that repair of single-strand DNA breaks is defective in senescent epithelial cells, which leads to an increased rate of mutations and the subsequent emergence of precancerous cells that have escaped senescence to gain an unlimited proliferative potential at a relative frequency of one in 10,000 senescent cells [82]. Moreover, the accumulation of DNA damage linked to an attenuated DNA damage response and repair in quiescent stem cells [77-79] may also promote the emergence of precancerous cells from normal quiescent cells.

\subsubsection{Activation of a sustained DNA dam-} age repair response (DDR). A consequence of aberrant DNA repair of lesion-containing base pairs could also be the generation of persistent SSBs [100, 101]. Alternatively, ab-BER could lead to futile cycles of DNA repair since damaged DNA bases are not removed by the aberrant excision/re-synthesis steps and after its completion ab-BER could be repeated. For instance, the preferential incorporation of adenosine opposite 8-oxo-dG may lead to adenine removal by MUTYH and incorporation of adenosine during the resynthesis step of ab-BER would reconstitute the initial DNA lesion [102]. Interestingly, in vitro experiments with the purified proteins and murine cell-free extracts demonstrated that following MUTYHcatalyzed excision of $\mathrm{A}$ in $\mathrm{A} \bullet 8$-oxoG mispair, DNA polymerase $\lambda$ in association with PCNA and RPA inserts the correct $\mathrm{C}$ opposite 8-oxoG with 1200-fold more efficiency as compared to the incorrect $\mathrm{A}$ thus avoiding the futile BER $[103,104]$. Importantly, the faithful DNA polymerase $\lambda$ dependent repair of $A \bullet 8-\mathrm{oxoG}$ mispair still necessitates the presence of OGG1 which removes 8 -oxoG from 8 -oxoG $\bullet C$ pair and restores native DNA sequence. Under certain circumstances such as increased oxidative stress and absence of OGG1, the MUTYHmediated BER can become futile and cytotoxic $[100,105]$. Indeed, it has been demonstrated that MUTYH induces persistent accumulation of SSBs in the nascent DNA strand which in turn promotes MLH1/PARP1dependent human cell death [106] and retinal inflammation and degeneration in a mouse model of Retinis pigmentosa [107].

The detrimental effects of futile DNA repair could manifest through a block of transcription if the damage occurs within a gene body. However, a more global effect on cell homeostasis could be the persistent activation of DNA damage response (DDR) pathways. Persistent DDR activation plays an essential 
causative role in the induction and maintenance of replicative cellular senescence [8284, 108-112]. Persistent DDR has been previously shown to trigger oxidative stress that could in turn enhance DNA damage and DDR through a positive feedback loop [93-95, 97, 98]. Furthermore, sustained DDR in senescent cells stimulates secretion of pro-inflammatory cytokines (Senescence Associated Secretory Phenotype or SASP) that could adversely affect the homeostasis of surrounding cells [113, 114]. It has to be evaluated whether ab-BER could substantially contribute to sustained DDR in senescent cells. Another interesting issue is whether ab-BER could induce a sustained DDR and an associated SASP that are linked to aging or dysfunction of terminally differentiated cells. A senescent-like state that was associated with severe DNA damage and features of DDR was recently demonstrated in aging neurons, which suggests that DNA damage could elicit similar responses in replication-competent and terminally differentiated cells [115]. Features characteristic of DDR and increased expression of the senescence-associated $\beta$-galactosidase, but not of the senescence-associated markers $\mathrm{p} 16$ and $\mathrm{p} 53$, was also identified in the neocortex of patients with Alzheimer's disease [116], which suggests that persistent DDR could significantly alter the homeostasis of terminally differentiated cells. A role of ab-BER in DDR was suggested by the study of the mechanisms of neurodegeneration caused by 3-nitropropionic acid (3NP) [100]. The authors showed that 3NP induced oxidative stress results in an accumulation of 8-oxoG and SSBs in the mitochondrial DNA of neurons. SSBs accumulation and neurodegeneration were alleviated in mutant mice lacking MUTYH, whereas OGG1 and MTH1, a 8-oxo-dGTP hydrolase, were being protective, suggesting that aberrant DNA repair of misincorporated adenosine opposite 8-oxo-dG by MUTYH leads to SSB accumulation which in turn triggers mitochondrial impairment and retrograde signalling to the nucleus of neurons.

\section{Possible link of aberrant DNA repair to natural aging processes}

Accumulation of DNA damage has been evidenced in non-dividing cells such as reversibly growth-arrested dormant hematopoietic stem cells $[78,79]$ or terminally differentiated neurons [87]. These conditions made growth-arrested cells prone to aberrant DNA repair as shown in hematopoietic dormant stem cells [77] since abundant and sustained DNA damages due to their ineffective or delayed repair could allow their processing by competing aberrant repair pathways leading to gene mutation and cellular dysfunction. Based on these observations we suggest that the removal of spontaneous and induced DNA damage in DNA repair deficient or in non-dividing mammalian cells could proceed in an aberrant manner leading to the generation and accumulation of mutant proteins in absence of DNA replication. This issue is relevant to both oncogenesis and degenerative diseases since quiescent cells include tissue-specific stem cells like hematopoietic or epithelial stem cells that are most of the time dormant as well as irreversibly growth-arrested differentiated cells like neurons or muscular cells. Here we hypothesize that the aberrant DNA glycosylase-initiated BER (ab-BER) pathway acting on the nondamaged strand in DNA duplex containing unrepaired oxidized DNA bases could lead to 
mutation fixation in cells in the absence of DNA replication [66].

Importantly, accumulation of ab-BER induced mutation in non-dividing cells would occur in highly heterogeneous manner since each cell in the cell population will acquire different mutations. To identify these mutations one would need to apply clonal selection: when cells would be allowed to grow under selective conditions to obtain resistant mutant clones. This process can be observed during malignant transformation when cells acquire multiple mutations which can be classified into two groups "driver" and "passenger" mutations. Analysis of mutations occurring in acute myeloid leukemia (AML) revealed that most of the mutations found in cancer genomes are random events that occurred in hematopoietic stem cells before they acquired the initiating mutation [117]. This observation may suggest that normal aging cells acquire mutation in random non-selective manner. In agreement with this, recent study of somatic mutations occurring in skin fibroblasts of healthy adult humans using DNA sequencing of single-cell genomes demonstrated that every cell contains at least one chromosomal rearrangement and 600-13,000 base substitutions [118]. Intriguingly, the spectra and correlation of base substitutions in healthy cells resemble many cancers suggesting that somatic cells also accumulate genetic changes due to endogenous mutagenic processes. These pre-existing, background mutations, which can be detected by single cell genome sequencing, can be at the origin of cancer and age-related diseases.

After reaching adulthood, individuals undergo at roughly equivalent rates a gradual degenerative process that finally results in death.
At present, it is not clear whether aging is programmed or whether maturation to adulthood is simply followed by spontaneous deterioration of vital body systems in the decades after reproductive years. Mutations in certain genes result in progeroid syndromes (or accelerated aging) (PS) which include Hutchinson Gilford, Werner, Cockayne and Dyskeratosis congenita syndromes which are characterized by signs of premature aging. More specifically, this accelerated aging is defined as the earlier than normal onset and increased frequency of an age-related attributes and disease, respectively. Importantly, these hereditary diseases which are also referred as segmental progeroid syndromes (sPS) only partially mimics signs of human aging. Clinical symptoms of sPS are skin atrophy with loss of cutaneous elasticity, mottled pigmentation, dysfunction of cutaneous appendices and of the central nervous system, degeneration, and an increased susceptibility for malignant tumors. If we assume that ab-BER can induce point mutations in non-dividing cells, then these cells would slowly accumulate mutations in time dependent manner. Consequently, mutations in coding DNA sequences would lead to accumulation of mutant proteins even in the absence of DNA replication. Increased level of the mutant proteins in non-dividing cells should saturate protein-chaperoning system and lead to general dysfunction of cellular metabolism (e.g., accumulation of abnormally folded amyloid beta protein in the brains of Alzheimer's patients). Therefore, each individual cell soon or later would acquire genetic mutations. In absence of clonal selection this process would result in generation of highly heterogeneous cell population in which missense mutations could occur in the proteins that are implicated in the 
progeroid syndromes such as Lamin A, Dyskerin, Werner and Cockayne syndrome proteins. Since all ab-BER induced mutations in non-dividing cells should occur in random heterogeneous manner, every cell in the aging tissue would contain different set of mutations. Therefore one would expect a "smeared" biological effect of these genetic mutations on the organism level. We may hypothesize that the natural aging process with gradual degradation of parts and systems of the human body is a manifestation of this "smeared" effect of abBER induced mutations in non-dividing cells. Thus, mutations induced by aberrant repair coupled to accumulation of DNA damage in non-dividing cells could be considered as one of the main factor of natural aging.

\section{Funding}

This work was supported by grants from la Ligue Nationale Française Contre le Cancer «Equipe LNCC 2016» and Electricité de France RB 2016-17 to M.S., Science Committee of the Ministry of Education and Science of the Republic of Kazakhstan, Program 0212/PTF14-OT and grant 3755/GF4 to B.T.M.

\section{REFERENCES.}

1. Bjelland S, Seeberg E. Mutagenicity, toxicity and repair of DNA base damage induced by oxidation. Mutat Res. 2003;531(1-2):37-80.

2. Cadet J, Douki T, Gasparutto D, Ravanat JL. Oxidative damage to DNA: formation, measurement and biochemical features. Mutat Res. 2003;531(12):5-23.

3. Dizdaroglu M. Oxidatively induced DNA damage: mechanisms, repair and disease. Cancer Lett. 2012;327(1-2):26-47.

4. Teoule $R$, Bert $C$, Bonicel A. Thymine fragment damage retained in the DNA polynucleotide chain after gamma irradiation in aerated solutions. II. Radiat Res. 1977;72(2):190-200.

5. Schuchmann MN, Steenken S, Wroblewski J, von Sonntag $C$. Site of $\mathrm{OH}$ radical attack on dihydrouracil and some of its methyl derivatives. Int $J$ Radiat Biol Relat Stud Phys Chem Med. 1984;46(3):225-32.

6. Ganguly T, Duker NJ. Stability of DNA thymine hydrates. Nucleic Acids Res. 1991;19(12):3319-23.

7. Grollman AP, Moriya M. Mutagenesis by 8-oxoguanine: an enemy within. Trends Genet. 1993;9(7):246-9.

8. Kreutzer DA, Essigmann JM. Oxidized, deaminated cytosines are a source of $\mathrm{C}-->\mathrm{T}$ transitions in vivo. Proc Natl Acad Sci U S A. 1998;95(7):3578-82.

9. Kunkel TA, Bebenek $K$. DNA replication fidelity. Annu Rev Biochem. 2000;69:497-529.

10. Kamiya H, Ueda T, Ohgi T, Matsukage A, Kasai H. Misincorporation of dAMP opposite 2-hydroxyadenine, an oxidative form of adenine. Nucleic Acids Res. 1995;23(5):761-6.

11. von Sonntag $C$. Free-radical-induced DNA damage and its repair: a chemical perspective. 2006. 1 ed. Springer-Verlag Berlin Heidelberg. 523 p.

12. Hix S, Morais Mda S, Augusto O. DNA methylation by tert-butyl hydroperoxide-iron (II). Free Radic Biol Med. 1995;19(3):293-301.

13. Hix S, Kadiiska MB, Mason RP, Augusto O. In vivo metabolism of tert-butyl hydroperoxide to methyl radicals. EPR spin-trapping and DNA methylation studies. Chem Res Toxicol. 2000;13(10):1056-64.

14. Kuraoka I, Bender C, Romieu A, Cadet J, Wood RD, Lindahl T. Removal of oxygen free-radical-induced 5',8-purine cyclodeoxynucleosides from DNA by the nucleotide excision-repair pathway in human cells. Proc Natl Acad Sci U S A. 2000;97(8):3832-7.

15. Wang J, Clauson CL, Robbins PD, Niedernhofer LJ, Wang $Y$. The oxidative DNA lesions 8,5'-cyclopurines accumulate with aging in a tissue-specific manner. Aging Cell. 2012;11(4):714-6.

16. Marnett LJ, Burcham PC. Endogenous DNA adducts: potential and paradox. Chem Res Toxicol. 1993;6(6):771-85.

17. Nair J, Barbin A, Guichard Y, Bartsch H. 1,N6ethenodeoxyadenosine and 3,N4-ethenodeoxycytine in liver DNA from humans and untreated rodents 
detected by immunoaffinity/32P-postlabeling. Carcinogenesis. 1995;16(3):613-7.

18. Bartsch H, Nair J. Ultrasensitive and specific detection methods for exocylic DNA adducts: markers for lipid peroxidation and oxidative stress. Toxicology. 2000;153(1-3):105-14.

19. Sidorenko VS, Yeo JE, Bonala RR, Johnson F, Schärer $O D$, Grollman AP. Lack of recognition by global-genome nucleotide excision repair accounts for the high mutagenicity and persistence of aristolactam-DNA adducts. Nucleic Acids Res. 2012;40(6):2494-505.

20. Kropachev K, Kolbanovskiy M, Liu Z, Cai Y, Zhang L, Schwaid AG, Kolbanovskiy A, Ding S, Amin S, Broyde S, Geacintov NE. Adenine-DNA adducts derived from the highly tumorigenic Dibenzo[a,l]pyrene are resistant to nucleotide excision repair while guanine adducts are not. Chem Res Toxicol. 2013;26(5):783-93.

21. Krokan HE, Bjørås M. Base excision repair. Cold Spring Harb Perspect Biol. 2013;5(4):a012583.

22. Yasui A. Alternative excision repair pathways. Cold Spring Harb. Perspect. Biol.,2013; 5:1-8.

23. Cunningham RP. DNA glycosylases. Mutat Res. 1997;383(3):189-96.

24. Dodson ML, Michaels ML, Lloyd RS. Unified catalytic mechanism for DNA glycosylases. $J$ Biol Chem. 1994;269(52):32709-12.

25. Demple B, Harrison $L$. Repair of oxidative damage to DNA: enzymology and biology. Annu Rev Biochem. 1994;63:915-48.

26. Ischenko AA, Saparbaev MK. Alternative nucleotide incision repair pathway for oxidative DNA damage. Nature. 2002;415(6868):183-7.

27. Gros L, Ishchenko AA, Ide H, Elder RH, Saparbaev $M K$. The major human AP endonuclease (Ape1) is involved in the nucleotide incision repair pathway. Nucleic Acids Res. 2004;32(1):73-81.

28. Ishchenko AA, Deprez E, Maksimenko A, Brochon $J C$, Tauc P, Saparbaev MK. Uncoupling of the base excision and nucleotide incision repair pathways reveals their respective biological roles. Proc Natl Acad Sci U S A. 2006;103(8):2564-9.

29. Lebedeva NA, Rechkunova NI, Lavrik OI. AP-site cleavage activity of tyrosyl-DNA phosphodiesterase 1. FEBS Lett. 2011;585(4):683-6.
30. Lebedeva NA, Rechkunova NI, El-Khamisy SF, Lavrik OI. Tyrosyl-DNA phosphodiesterase 1 initiates repair of apurinic/apyrimidinic sites. Biochimie. 2012;94(8):1749-53.

31. Lebedeva NA, Rechkunova NI, Ishchenko AA, Saparbaev $M$, Lavrik OI. The mechanism of human tyrosyl-DNA phosphodiesterase 1 in the cleavage of AP site and its synthetic analogs. DNA Repair (Amst). 2013;12(12):1037-42.

32. Wiederhold L, Leppard JB, Kedar P, Karimi-Busheri F, Rasouli-Nia A, Weinfeld M, Tomkinson AE, Izumi T, Prasad R, Wilson SH, Mitra S, Hazra TK. AP endonuclease-independent DNA base excision repair in human cells. Mol Cell. 2004;15(2):209-20.

33. Das A, Wiederhold L, Leppard JB, Kedar P, Prasad R, Wang H, Boldogh I, Karimi-Busheri F, Weinfeld M, Tomkinson AE, Wilson SH, Mitra S, Hazra TK. NEIL2-initiated, APE-independent repair of oxidized bases in DNA: Evidence for a repair complex in human cells. DNA Repair (Amst). 2006;5(12):1439-48.

34. Brooks PJ, Wise DS, Berry DA, Kosmoski JV, Smerdon MJ, Somers RL, Mackie H, Spoonde AY, Ackerman EJ, Coleman K, Tarone RE, Robbins JH. The oxidative DNA lesion 8,5'-(S)-cyclo-2'-deoxyadenosine is repaired by the nucleotide excision repair pathway and blocks gene expression in mammalian cells. J Biol Chem. 2000;275(29):22355-62.

35. Johnson KA, Fink SP, Marnett LJ. Repair of propanodeoxyguanosine by nucleotide excision repair in vivo and in vitro. $J$ Biol Chem. 1997;272(17):11434-8.

36. Marteijn JA, Lans H, Vermeulen W, Hoeijmakers $J H$. Understanding nucleotide excision repair and its roles in cancer and ageing. Nat Rev Mol Cell Biol. 2014;15(7):465-81.

37. Pande P, Das RS, Sheppard C, Kow YW, Basu AK. Repair efficiency of (5'S)-8,5'-cyclo-2'-deoxyguanosine and (5'S)-8,5'-cyclo-2'-deoxyadenosine depends on the complementary base. DNA Repair (Amst). 2012;11(11):926-31.

38. Theron T, Fousteri MI, Volker M, Harries $L W$, Botta E, Stefanini M, Fujimoto M, Andressoo JO, Mitchell J, Jaspers NG, McDaniel LD, Mullenders LH, Lehmann AR. Transcription-associated breaks in xeroderma pigmentosum group D cells 
from patients with combined features of xeroderma pigmentosum and Cockayne syndrome. Mol Cell Biol. 2005;25(18):8368-78.

39. de Laat WL, Appeldoorn E, Sugasawa K, Weterings $E$, Jaspers $N G$, Hoeijmakers $J H$. DNA-binding polarity of human replication protein A positions nucleases in nucleotide excision repair. Genes Dev. 1998;12(16):2598-609.

40. Jiricny J. MutLalpha: at the cutting edge of mismatch repair. Cell. 2006;126(2):239-41.

41. Peña-Diaz J, Bregenhorn S, Ghodgaonkar M, Follonier C, Artola-Borán M, Castor D, Lopes M, Sartori AA, Jiricny J. Noncanonical mismatch repair as a source of genomic instability in human cells. Mol Cell. 2012;47(5):669-80.

42. Zlatanou A, Despras E, Braz-Petta T, BoubakourAzzouz I, Pouvelle C, Stewart GS, Nakajima S, Yasui A, Ishchenko AA, Kannouche PL. The hMsh2hMsh6 complex acts in concert with monoubiquitinated PCNA and Pol $\eta$ in response to oxidative DNA damage in human cells. Mol Cell. 2011;43(4):649-62.

43. Berdal KG, Johansen RF, Seeberg E. Release of normal bases from intact DNA by a native DNA repair enzyme. EMBO J. 1998;17(2):363-7.

44. Xiao $W$, Samson $L$. In vivo evidence for endogenous DNA alkylation damage as a source of spontaneous mutation in eukaryotic cells. Proc Natl Acad Sci U S A. 1993;90(6):2117-21.

45. Leitner-Dagan Y, Sevilya Z, Pinchev M, Kramer $R$, Elinger D, Roisman LC, Rennert HS, Schechtman E, Freedman L, Rennert G, Livneh Z, Paz-Elizur T. Nmethylpurine DNA glycosylase and OGG1 DNA repair activities: opposite associations with lung cancer risk. J Natl Cancer Inst. 2012;104(22):1765-9.

46. Branum ME, Reardon JT, Sancar A. DNA repair excision nuclease attacks undamaged DNA. A potential source of spontaneous mutations. $J$ Biol Chem. 2001;276(27):25421-6.

47. Mu D, Bessho T, Nechev LV, Chen DJ, Harris TM, Hearst JE, Sancar A. DNA interstrand cross-links induce futile repair synthesis in mammalian cell extracts. Mol Cell Biol. 2000;20(7):2446-54.

48. Chan KK, Zhang QM, Dianov GL. Base excision repair fidelity in normal and cancer cells. Mutagenesis. 2006;21(3):173-8.
49. Modrich P, Lahue R. Mismatch repair in replication fidelity, genetic recombination, and cancer biology. Annu Rev Biochem. 1996;65:101-33.

50. Wong E, Yang K, Kuraguchi M, Werling U, Avdievich E, Fan K, Fazzari M, Jin B, Brown AM, Lipkin $M$, Edelmann $W$. Mbd4 inactivation increases Cright-arrowT transition mutations and promotes gastrointestinal tumor formation. Proc Natl Acad Sci U S A. 2002;99(23):14937-42.

51. Hirano S, Tominaga Y, Ichinoe A, Ushijima $Y$, Tsuchimoto D, Honda-Ohnishi Y, Ohtsubo T, Sakumi K, Nakabeppu Y. Mutator phenotype of MUTYH-null mouse embryonic stem cells. J Biol Chem. 2003;278(40):38121-4.

52. Tsai-Wu JJ, Radicella JP, Lu AL. Nucleotide sequence of the Escherichia coli micA gene required for A/G-specific mismatch repair: identity of micA and mutY. J Bacteriol. 1991;173(6):1902-10.

53. Michaels ML, Cruz C, Grollman AP, Miller JH. Evidence that MutY and MutM combine to prevent mutations by an oxidatively damaged form of guanine in DNA. Proc Natl Acad Sci U S A. 1992;89(15):7022-5.

54. Michaels ML, Pham L, Nghiem Y, Cruz C, Miller JH. MutY, an adenine glycosylase active on G-A mispairs, has homology to endonuclease III. Nucleic Acids Res. 1990;18(13):3841-5.

55. Fowler RG, White SJ, Koyama C, Moore SC, Dunn $R L$, Schaaper RM. Interactions among the Escherichia coli mutT, mutM, and mutY damage prevention pathways. DNA Repair (Amst). 2003;2(2):159-73.

56. Sieber OM, Lipton L, Crabtree M, Heinimann K, Fidalgo P, Phillips RK, Bisgaard ML, Orntoft TF, Aaltonen LA, Hodgson SV, Thomas HJ, Tomlinson IP. Multiple colorectal adenomas, classic adenomatous polyposis, and germ-line mutations in MYH. N Engl J Med. 2003;348(9):791-9.

57. Parker A, Gu Y, Mahoney W, Lee SH, Singh KK, $\mathrm{Lu} A L$. Human homolog of the MutY repair protein (hMYH) physically interacts with proteins involved in long patch DNA base excision repair. $J$ Biol Chem. 2001;276(8):5547-55.

58. Hayashi H, Tominaga Y, Hirano S, McKenna AE, Nakabeppu Y, Matsumoto Y. Replication-associated repair of adenine:8-oxoguanine mispairs by MYH. Curr Biol. 2002;12(4):335-9. 
59. Hashimoto K, Tominaga Y, Nakabeppu Y, Moriya M. Futile short-patch DNA base excision repair of adenine:8-oxoguanine mispair. Nucleic Acids Res. 2004;32(19):5928-34.

60. Shi G, Chang DY, Cheng CC, Guan X, Venclovas C, $\mathrm{Lu} A L$. Physical and functional interactions between MutY glycosylase homologue (MYH) and checkpoint proteins Rad9-Rad1-Hus1. Biochem $J$. 2006;400(1):53-62.

61. Hwang BJ, Jin J, Gunther R, Madabushi A, Shi G, Wilson GM, Lu AL. Association of the Rad9-Rad1Hus1 checkpoint clamp with MYH DNA glycosylase and DNA. DNA Repair (Amst). 2015;31:80-90.

62. Turco E, Ventura I, Minoprio A, Russo MT, Torreri P, Degan P, Molatore S, Ranzani GN, Bignami M, Mazzei F. Understanding the role of the Q338H MUTYH variant in oxidative damage repair. Nucleic Acids Res. 2013;41(7):4093-103.

63. Brinkmeyer MK, David SS. Distinct functional consequences of MUTYH variants associated with colorectal cancer: Damaged DNA affinity, glycosylase activity and interaction with PCNA and Hus1. DNA Repair (Amst). 2015;34:39-51.

64. Gu Y, Parker A, Wilson TM, Bai H, Chang DY, $L u A L$. Human MutY homolog, a DNA glycosylase involved in base excision repair, physically and functionally interacts with mismatch repair proteins human MutS homolog 2/human MutS homolog 6. J Biol Chem. 2002;277(13):11135-42.

65. Repmann S, Olivera-Harris M, Jiricny J. Influence of oxidized purine processing on strand directionality of mismatch repair. J Biol Chem. 2015;290(16): 9986-99.

66. Talhaoui I, Couve S, Gros L, Ishchenko AA, Matkarimov B, Saparbaev MK. Aberrant repair initiated by mismatch-specific thymine-DNA glycosylases provides a mechanism for the mutational bias observed in $\mathrm{CpG}$ islands. Nucleic Acids Res. 2014;42(10):6300-13.

67. Cortázar D, Kunz C, Selfridge J, Lettieri T, Saito Y, MacDougall E, Wirz A, Schuermann D, Jacobs AL, Siegrist F, Steinacher R, Jiricny J, Bird A, Schär P. Embryonic lethal phenotype reveals a function of TDG in maintaining epigenetic stability. Nature. 2011;470(7334):419-23.
68. Cortellino $S, X u$ J, Sannai M, Moore R, Caretti E, Cigliano A, Le Coz M, Devarajan K, Wessels A, Soprano D, Abramowitz LK, Bartolomei MS, Rambow F, Bassi MR, Bruno T, Fanciulli M, Renner C, Klein-Szanto AJ, Matsumoto Y, Kobi D, Davidson I, Alberti C, Larue L, Bellacosa A. Thymine DNA glycosylase is essential for active DNA demethylation by linked deamination-base excision repair. Cell. 2011;146(1):67-79.

69. O'Brien PJ, Ellenberger T. The Escherichia coli 3-methyladenine DNA glycosylase AlkA has a remarkably versatile active site. $J$ Biol Chem. 2004;279(26):26876-84.

70. O'Brien PJ, Ellenberger T. Dissecting the broad substrate specificity of human 3-methyladenine-DNA glycosylase. J Biol Chem. 2004;279(11):9750-7.

71. Shinmura K, Yamaguchi S, Saitoh T, Takeuchi-Sasaki M, Kim SR, Nohmi T, Yokota J. Adenine excisional repair function of MYH protein on the adenine:8-hydroxyguanine base pair in double-stranded DNA. Nucleic Acids Res. 2000;28(24):4912-8.

72. Pope MA, David SS. DNA damage recognition and repair by the murine MutY homologue. DNA Repair (Amst). 2005;4(1):91-102.

73. Ushijima Y, Tominaga Y, Miura T, Tsuchimoto D, Sakumi K, Nakabeppu Y. A functional analysis of the DNA glycosylase activity of mouse MUTYH protein excising 2-hydroxyadenine opposite guanine in DNA. Nucleic Acids Res. 2005;33(2):672-82.

74. Bielas JH, Heddle JA. Quiescent murine cells lack global genomic repair but are proficient in transcriptioncoupled repair. DNA Repair (Amst). 2004;3(7):711-7.

75. Fortini P, Dogliotti E. Mechanisms of dealing with DNA damage in terminally differentiated cells. Mutat Res. 2010;685(1-2):38-44.

76. Nouspikel T. DNA repair in differentiated cells: some new answers to old questions. Neuroscience. 2007;145(4):1213-21.

77. Mohrin M, Bourke E, Alexander D, Warr MR, Barry-Holson K, Le Beau MM, Morrison CG, Passegué E. Hematopoietic stem cell quiescence promotes error-prone DNA repair and mutagenesis. Cell Stem Cell. 2010;7(2):174-85.

78. Rossi DJ, Seita J, Czechowicz A, Bhattacharya D, Bryder D, Weissman IL. Hematopoietic stem cell 
quiescence attenuates DNA damage response and permits DNA damage accumulation during aging. Cell Cycle. 2007;6(19):2371-6.

79. Beerman I, Seita J, Inlay MA, Weissman IL, Rossi DJ. Quiescent hematopoietic stem cells accumulate DNA damage during aging that is repaired upon entry into cell cycle. Cell Stem Cell. 2014;15(1):37-50.

80. Chen Y, Li D, Wang D, Liu X, Yin N, Song Y, Lu SH, Ju $Z$, Zhan $Q$. Quiescence and attenuated DNA damage response promote survival of esophageal cancer stem cells. J Cell Biochem. 2012;113(12): 3643-52

81. Garinis GA, Uittenboogaard LM, Stachelscheid H, Fousteri M, van Ijcken W, Breit TM, van Steeg $H$, Mullenders LH, van der Horst GT, Brüning JC, Niessen CM, Hoeijmakers JH, Schumacher B. Persistent transcription-blocking DNA lesions trigger somatic growth attenuation associated with longevity. Nat Cell Biol. 2009;11(5):604-15.

82. Nassour J, Martien S, Martin N, Deruy E, Tomellini E, Malaquin N, Bouali F, Sabatier L, Wernert N, Pinte S, Gilson E, Pourtier A, Pluquet O, Abbadie C. Defective DNA single-strand break repair is responsible for senescence and neoplastic escape of epithelial cells. Nat Commun. 2016;7:10399.

83. Fumagalli M, Rossiello F, Mondello C, d'Adda di Fagagna F. Stable cellular senescence is associated with persistent DDR activation. PLoS One. 2014; 9(10):e110969.

84. Mallette FA, Ferbeyre G. The DNA damage signaling pathway connects oncogenic stress to cellular senescence. Cell Cycle. 2007;6(15):1831-6.

85. Suzuki M, Suzuki K, Kodama S, Yamashita S, Watanabe $M$. Persistent amplification of DNA damage signal involved in replicative senescence of normal human diploid fibroblasts. Oxid Med Cell Longev. 2012;2012:310534.

86. Yahata T, Takanashi T, Muguruma Y, Ibrahim AA, Matsuzawa H, Uno T, Sheng Y, Onizuka M, Ito M, Kato $S$, Ando $K$. Accumulation of oxidative DNA damage restricts the self-renewal capacity of human hematopoietic stem cells. Blood. 2011;118(11):2941-50.

87. Sykora P, Wilson DM 3rd, Bohr VA. Base excision repair in the mammalian brain: implication for age related neurodegeneration. Mech Ageing Dev. 2013;134(10):440-8.
88. Gaubatz JW, Tan BH. Aging affects the levels of DNA damage in postmitotic cells. Ann N Y Acad Sci. 1994;719:97-107.

89. Tan BH, Bencsath FA, Gaubatz JW. Steady-state levels of 7-methylguanine increase in nuclear DNA of postmitotic mouse tissues during aging. Mutat Res. 1990;237(5-6):229-38.

90. Hinz JM, Rodriguez Y, Smerdon MJ. Rotational dynamics of DNA on the nucleosome surface markedly impact accessibility to a DNA repair enzyme. Proc Natl Acad Sci U S A. 2010;107(10):4646-51.

91. Odell ID, Barbour JE, Murphy DL, Della-Maria JA, Sweasy JB, Tomkinson AE, Wallace SS, Pederson $D S$. Nucleosome disruption by DNA ligase III-XRCC1 promotes efficient base excision repair. Mol Cell Biol. 2011;31(22):4623-32.

92. Prakash S, Johnson RE, Prakash L. Eukaryotic translesion synthesis DNA polymerases: specificity of structure and function. Annu Rev Biochem. 2005;74:317-53.

93. Passos JF, Nelson G, Wang C, Richter T, Simillion C, Proctor CJ, Miwa S, Olijslagers S, Hallinan J, Wipat A, Saretzki G, Rudolph KL, Kirkwood TB, von Zglinicki T. Feedback between p21 and reactive oxygen production is necessary for cell senescence. Mol Syst Biol. 2010;6:347.

94. Macip S, Igarashi M, Fang L, Chen A, Pan ZQ, Lee SW, Aaronson SA. Inhibition of p21-mediated ROS accumulation can rescue p21-induced senescence. EMBO J. 2002;21(9):2180-8.

95. Hubackova S, Krejcikova K, Bartek J, Hodny Z. IL1- and TGF $\beta$-Nox4 signaling, oxidative stress and DNA damage response are shared features of replicative, oncogene-induced, and drug-induced paracrine 'bystander senescence'. Aging (Albany NY). 2012;4(12):932-51.

96. Chen Q, Fischer A, Reagan JD, Yan LJ, Ames BN. Oxidative DNA damage and senescence of human diploid fibroblast cells. Proc Natl Acad Sci U S A. 1995;92(10):4337-41.

97. Zhu D, Wu J, Spee C, Ryan SJ, Hinton DR. BMP4 mediates oxidative stress-induced retinal pigment epithelial cell senescence and is overexpressed in age-related macular degeneration. J Biol Chem. 2009;284(14):9529-39. 
98. Kretova M, Sabova L, Hodny Z, Bartek J, Kollarovic $G$, Nelson BD, Hubackova $S$, Luciakova $K$. TGF- $\beta$ /NF1/Smad4-mediated suppression of ANT2 contributes to oxidative stress in cellular senescence. Cell Signal. 2014;26(12):2903-11.

99. Kennedy L, Evans E, Chen CM, Craven L, Detloff PJ, Ennis M, Shelbourne PF. Dramatic tissuespecific mutation length increases are an early molecular event in Huntington disease pathogenesis. Hum Mol Genet. 2003;12(24):3359-67.

100. Sheng Z, Oka S, Tsuchimoto D, Abolhassani N, Nomaru H, Sakumi K, Yamada H, Nakabeppu Y. 8-Oxoguanine causes neurodegeneration during MUTYH-mediated DNA base excision repair. J Clin Invest. 2012;122(12):4344-61.

101. Vrouwe $M G$, Pines A, Overmeer RM, Hanada $K$, Mullenders $L H$. UV-induced photolesions elicit ATR-kinase-dependent signaling in non-cycling cells through nucleotide excision repair-dependent and -independent pathways. J Cell Sci. 2011;124 (Pt 3):435-46.

102. Oka S, Ohno M, Tsuchimoto D, Sakumi K, Furuichi M, Nakabeppu $Y$. Two distinct pathways of cell death triggered by oxidative damage to nuclear and mitochondrial DNAs. EMBO J. 2008;27(2):421-32.

103. Maga G, Villani $G$, Crespan E, Wimmer U, Ferrari E, Bertocci B, Hübscher U. 8-oxo-guanine bypass by human DNA polymerases in the presence of auxiliary proteins. Nature. 2007;447(7144): 606-8.

104. Maga G, Crespan E, Wimmer U, van Loon B, Amoroso A, Mondello C, Belgiovine C, Ferrari E, Locatelli $G$, Villani $G$, Hübscher $U$. Replication protein A and proliferating cell nuclear antigen coordinate DNA polymerase selection in 8-oxoguanine repair. Proc Natl Acad Sci USA. 2008;105(52):20689-94.

105. Nakabepри Y. Cellular levels of 8-oxoguanine in either DNA or the nucleotide pool play pivotal roles in carcinogenesis and survival of cancer cells. Int $J$ Mol Sci. 2014;15(7):12543-57.

106. Oka S, Leon J, Tsuchimoto D, Sakumi K, Nakaьерри $Y$. MUTYH, an adenine DNA glycosylase, mediates p53 tumor suppression via PARP-dependent cell death. Oncogenesis. 2014;3:e121.
107. Nakatake S, Murakami Y, Ikeda Y, Morioka N, Tachibana T, Fujiwara K, Yoshida N, Notomi S, Hisatomi T, Yoshida S, Ishibashi T, Nakabeppu Y, Sonoda KH. MUTYH promotes oxidative microglial activation and inherited retinal degeneration. JCI Insight. 2016;1(15):e87781.

108. Bartkova J, Rezaei N, Liontos M, Karakaidos P, Kletsas D, Issaeva N, Vassiliou LV, Kolettas E, Niforou K, Zoumpourlis VC, Takaoka M, Nakagawa H, Tort F, Fugger K, Johansson F, Sehested M, Andersen CL, Dyrskjot L, Ørntoft T, Lukas J, Kittas C, Helleday T, Halazonetis TD, Bartek J, Gorgoulis $V G$. Oncogene-induced senescence is part of the tumorigenesis barrier imposed by DNA damage checkpoints. Nature. 2006;444(7119):633-7.

109. Toledo LI, Murga M, Gutierrez-Martinez P, Soria $R$, Fernandez-Capetillo $O$. ATR signaling can drive cells into senescence in the absence of DNA breaks. Genes Dev. 2008;22(3):297-302.

110. Cheung CT, Singh R, Kalra RS, Kaul SC, Wadhwa $R$. Collaborator of ARF (CARF) regulates proliferative fate of human cells by dose-dependent regulation of DNA damage signaling. J Biol Chem. 2014;289(26):18258-69.

111. d'Adda di Fagagna F, Reaper PM, Clay-Farrace L, Fiegler H, Carr P, Von Zglinicki T, Saretzki G, Carter NP, Jackson SP. A DNA damage checkpoint response in telomere-initiated senescence. Nature. 2003;426(6963):194-8.

112. Minieri V, Saviozzi S, Gambarotta G, Lo Iacono M, Accomasso L, Cibrario Rocchietti E, Gallina C, Turinetto V, Giachino C. Persistent DNA damageinduced premature senescence alters the functional features of human bone marrow mesenchymal stem cells. J Cell Mol Med. 2015;19(4):734-43.

113. Kuilman T, Michaloglou C, Vredeveld LC, Douma $S$, van Doorn R, Desmet CJ, Aarden LA, Mooi WJ, Peeper DS. Oncogene-induced senescence relayed by an interleukin-dependent inflammatory network. Cell. 2008;133(6):1019-31.

114. Rodier F, Coppé JP, Patil CK, Hoeijmakers WA, Muñoz DP, Raza SR, Freund A, Campeau E, Davalos AR, Campisi J. Persistent DNA damage signalling triggers senescence-associated inflammatory cytokine secretion. Nat Cell Biol. 2009;11(8):973-9. 
115. Jurk D, Wang C, Miwa S, Maddick M, Korolchuk V, Tsolou A, Gonos ES, Thrasivoulou C, Saffrey MJ, Cameron $K$, von Zglinicki T. Postmitotic neurons develop a p21-dependent senescence-like phenotype driven by a DNA damage response. Aging Cell. 2012;11(6):996-1004.

116. Simpson JE, Ince PG, Matthews FE, Shaw PJ, Heath PR, Brayne C, Garwood C, Higginbottom A, Wharton SB; MRC Cognitive Function and Ageing Neuropathology Study Group.. A neuronal DNA damage response is detected at the earliest stages of Alzheimer's neuropathology and correlates with cognitive impairment in the Medical Research Council's Cognitive Function and Ageing Study ageing brain cohort. Neuropathol Appl Neurobiol. 2015;41(4):483-96.

117. Welch JS, Ley TJ, Link DC, Miller CA, Larson DE, Koboldt DC, Wartman LD, Lamprecht TL, Liu F, Xia J, Kandoth C, Fulton RS, McLellan MD, Dooling DJ, Wallis JW, Chen K, Harris CC, Schmidt HK, KalickiVeizer JM, Lu C, Zhang Q, Lin L, O'Laughlin MD, McMichael JF, Delehaunty KD, Fulton LA, Magrini VJ, McGrath SD, Demeter RT, Vickery TL, Hundal J, Cook LL, Swift GW, Reed JP, Alldredge PA, Wylie TN, Walker JR, Watson MA, Heath SE, Shannon WD, Varghese N, Nagarajan R, Payton JE, Baty JD, Kulkarni S, Klco JM, Tomasson MH, Westervelt P, Walter MJ, Graubert TA, DiPersio JF, Ding L, Mardis ER, Wilson $R K$. The origin and evolution of mutations in acute myeloid leukemia. Cell. 2012;150(2):264-78.

118. Saini N, Roberts SA, Klimczak LJ, Chan K, Grimm $S A$, Dai S, Fargo DC, Boyer JC, Kaufmann WK, Taylor JA, Lee E, Cortes-Ciriano I, Park PJ, Schurman SH, Malc EP, Mieczkowski PA, Gordenin DA. The Impact of Environmental and Endogenous Damage on Somatic Mutation Load in Human Skin Fibroblasts. PLoS Genet. 2016;12(10):e1006385.

\section{Аберрантна ДНК глікозілазная репарація ушкоджень ДНК індукованих вільними радикалами кисню: Значення для розуміння причин природньогостаріння і хвороб пов'язаних зі старінням}

Б. Т. Маткаримов, М. К. Сапарбаєв

Аеробне клітинне дихання генерує активні форми кисню (ROS), які можуть пошкоджувати макромоле- кули, включаючи ліпіди, білки і ДНК. В даний час вважається, що старіння є наслідком природного i незворотного накопичення окисних ушкоджень в клітинній ДНК. В середньому приблизно в кожній клітині людини відбувається від 2000 до 8000 пошкоджень ДНК за годину або приблизно від 40000 до 200000 пошкоджень на клітку на день. Системи репарації ДНК здатні розрізняти нормальні неушкоджені і модифіковані основи ДНК. Наприклад, ДНК глікозілази специфічно розпізнають і видаляють пошкоджені основи серед безлічі нормальних непошкоджених основ при ексцизійній репарації основ (base excision repair, BER). Проте через спонтанні конверсії 5-метілцітозіна у тимін, а також помилки ДНК-полімерази під час реплікації можуть виникати помилково спарені неушкоджені основи ДНК. Щоб протидіяти мутаціям що виникають через помилкове спарювання основ і становлять загрозу стабільності геному, клітини в процесі еволюції розвинули спеціальні системи репарації ДНК, які можуть видаляти помилково вбудовані або неспарені нормальні основи у непошкодженому ланцюга ДНК в дуплексі. Шлях репарації BER за участю Аденін- i Тимин-ДНК-глікозілаз (MutY / MUTYH i TDG / MBD4, відповідно) специфічних до неспареним підставах в дуплексі ДНК, а також шлях репарації помилково спарених некомплементарни пар основ (mismatch repair, MMR) можуть розпізнавати і видаляти нормальні неушкоджені основи в помилково спарених парах основ в дуплексах ДНК. Парадоксально, але при певних обставинах в клітинах дефіцитних по репарації ДНК, бактеріальна ДНК глікозілаза MutY і людська ДНК глікозілаза TDG можуть діяти аберрантним шляхом: MutY i TDG видаляють помилково спарені аденін і тимін які знаходяться навпроти 8-оксогуаніна і пошкодженого аденіну, відповідно. Ці аберрантние ферментні реакції призводять або до мутацій, або до марної циклічної репарації ДНК, що вказує на те, що шляхи репарації ДНК, які спрямовані на неушкоджену ланцюг ДНК в дуплексі, можуть діяти аномально і приводити до нестабільності генома в присутності нерепарованних пошкоджень ДНК. Описано факти, які свідчать що крім накопичення окисного пошкодження ДНК в клітинах, аберрантна репарація ДНК може також сприяти таким захворюванням як рак, дегенеративні зміни в головному мозку і передчасне 
старіння. У цьому огляді підсумовані наявні знання про аберрантні шляхи репарації ДНК окисних пошкоджень ДНК і їхн можлива роль у старінні.

К л ю ч о в і с л о в а: окисне пошкодження ДНК, кристалічна структура, екзиційна репарація основ, АР ендонуклеаза.

\section{Аберрантная ДНК гликозилазная репарация повреждений ДНК индуцированных свободными радикалами кислорода: Значение для понимания причин естественного старения и болезней связанных со старением}

Б. Т. Маткаримов, М. К. Сапарбаев

Аэробное клеточное дыхание генерирует активные формы кислорода (ROS), которые могут повреждать макромолекулы, включая липиды, белки и ДНК. В настоящее время предполагается, что старение является следствием естественного и необратимого накопления окислительных повреждений в клеточной ДНК. В среднем приблизительно в каждой клетке человека происходит от 2000 до 8000 повреждений ДНК в час или приблизительно от 40000 до 200000 повреждений на клетку в день. Системы репарации ДНК способны различать между нормальными неповрежденными и модифицированными основаниями ДНК. Например, ДНК гликозилазы специфически распознают и удаляют поврежденные основания среди множества нормальных неповрежденных оснований в пути называемой эксцизионной репарацией оснований (base excision repair, BER). Однако из-за спонтанной конверсии 5-метилцитозина в тимин, а также ошибок ДНКполимеразы во время репликации в природе могут возникать ошибочно спаренные неповрежденные основания ДНК. Чтобы противодействовать мутациям возникающим из-за ошибочного спаривания оснований и представляющих угрозу стабильности генома, клетки в процессе эволюции развили специальные системы репарации ДНК, которые могут удалять ошибочно встроенные или неспаренные нормальные основания в неповрежденной цепи ДНК в дуплексе. Путь репарации BER с участием Аденин- и Тимин-ДНКгликозилаз (MutY/MUTYH и TDG/MBD4, соответственно) специфичных к неспаренным основаниям в дуплексе ДНК, а также путь репарации ошибочно спаренных некомплементарных пар оснований (mismatch repair, MMR) могут распознавать и удалять нормальные неповрежденные основания в ошибочно спаренных парах оснований в дуплексах ДНК. Парадоксально, но при определенных обстоятельствах в клетках дефицитных по репарации ДНК, бактериальная ДНК гликозилаза MutY и человеческая ДНК гликозилаза TDG могут действовать аберрантным путем: MutY и TDG удаляют ошибочно спаренные аденин и тимин которые находятся напротив 8-оксогуанина и поврежденного аденина, соответственно. Эти аберрантные энзиматические реакции приводят либо к мутациям, либо к бесполезной циклической репарации ДНК, что указывает на то, что пути репарации ДНК, которые направлены на неповрежденную цепь ДНК в дуплексе, могут действовать аномально и приводить к нестабильности генома в присутствии нерепарированных повреждений ДНК. Описаны факты, свидетельствующие о том, что помимо накопления окислительного повреждения ДНК в клетках, аберрантная репарация ДНК может также способствовать таким заболеваниям как рак, дегенеративные изменения в головном мозге и преждевременное старение. В этом обзоре суммированы имеющиеся знания об аберрантных путях репарации ДНК для окислительных повреждений ДНК и их возможная роль в старении.

Кл юч е в ы е с л о в а: окислительные повреждения ДНК, кристаллическая структура, эксцизионная репарация оснований, АР эндонуклеаза.

Received 11.11.2016 